\title{
ASSOCIATION OF POSITIVE FAMILY HISTORY WITH BREAST CANCER IN YOUNG FEMALES WITH BREAST LUMPS.
}

\author{
DR. MARIA TARIQ, MBBS \\ NISHTAR HOSPITAL, MULTAN, PAKISTAN.
}

DR. HUMA JAVAID, MBBS

NISHTAR HOSPITAL, MULTAN, PAKISTAN.

DR. MIAN AAMIR FIAZ, MBBS

MEDICAL OFFICER, DHQ HOSPITAL, MUZAFFAR GARH, PAKISTAN.

\begin{abstract}
;
Background; Breast cancer is most frequently diagnosed cancer in females. It has a major impact on health of women. According to a World Health Organization [WHO] estimate, more than 1.2 million people are diagnosed with breast cancer worldwide every year. This study was conducted to determine the frequency of breast cancer in patients presenting with breast lumps in our population. OBJECTIVE; To determine frequency of breast cancer among young females presenting with breast lumps at a tertiary care hospital. Material and Methods; Consecutive 160 young ladies presenting with breast lumps were taken. Young females with breast lumps were taken and diagnosed for breast cancer. All the data was entered and analyzed using SPSS-20. Results; Of these 160 study cases, $98(61.2 \%)$ were un-married female patients while $62(38.8 \%)$ were married female patients. Mean age of our study cases was $23.23 \pm 3.85$ years (with minimum age of our study cases was 18 years while maximum age was 32 years). Our study results have indicated that majority of our study cases i.e. 123 (76.9\%) were aged up to 25 years. Mean body mass index of our study cases was $26.23 \pm 1.92 \mathrm{~kg} / \mathrm{m}^{2}$ and obesity was present in $48(30.0 \%)$. Mean disease duration was $2.98 \pm 2.54$ months and $111(69.4 \%)$ had duration of illness up to 3 months. Breast cancer was noted in $40(25.0 \%)$ of our study cases.
\end{abstract}

Conclusion; High frequency of breast cancer was noted in our study among young females presenting with breast lumps. Breast cancer was significantly associated with marital status, increasing age, residential status, socioeconomic status and family history of breast cancer. These findings suggest that females at every age group with breast lumps need specialized care for diagnosis and management.

Keywords; Breast Cancer, Breast Lumps, Young Females.

DOI: $10.7176 / \mathrm{JMPB} / 54-18$

Publication date: April $30^{\text {th }} 2019$ 


\section{INTRODUCTION;}

More than one million new patients suffer from breast cancer annually in the world ${ }^{1,2}$. In 2008 , approximately 1.38 million new cases were diagnosed and approximately 458,000deaths were recorded both in developed and developing countries ${ }^{3}$. In developed countries, breast cancer is the most common malignancy diagnosed among women, and in developing regions, it ranks second to cervical cancer ${ }^{2}$. Among American women, breast cancer represents $32 \%$ of all new patients of cancer and is the second leading cause of cancer deaths $(15 \%)$ after lung cancer. The WHO estimates that by the year 2020, the number of cases of cancer will double in developing countries ${ }^{4}$.

The incidence of breast cancer in younger women differs according to race. Though it rarely occurs in young women but breast cancer at younger ages has been reported to have a more aggressive behavior and unfavorable prognosis compared to the older patients. In breast cancer, young refers to women 40 years and below. In young women, the incidence of the disease is low (less than 17 cases per 100,000) women or less than $6 \%$ of all breast cancers among women of any age ${ }^{5}$. However, accumulating evidence suggests that breast cancer in this age group is more aggressive and associated with poorer outcome than in their older counterparts. Although some reports have identified young age at diagnosis as an adverse prognostic indicator, this could be ascribed to a combination of factors, including delayed presentation, advanced disease stage, and unfavorable tumor characteristics ${ }^{6,7}$. So early identification and diagnosis remains cornerstone for the desired outcomes which can be achieved through screening them particularly those with breast lumps where it can be as $11.7 \%$ ( 25 out of 214 ) as reported in one study ${ }^{8}$.

Breast cancer in young ages is complex disease to manage which leads to poor prognosis mostly due to the factors like late presentation. The study results will generate useful database of our local population which will be compared with other studies from different parts of the world.

\section{MATERIAL AND METHODS;}

Consecutive 160 young ladies presenting with breast lumps were taken. Patients having breast lumps were enrolled in this study from OPD of department of Surgery, Nishtar Hospital, Multan. Previous history of breast cancer, additional malignancies in other body parts and patients which don't give consent of participation were excluded from our study. Young females with breast lumps were taken and diagnosed for breast cancer (diagnosed on histopathology of the biopsied specimen revealing atypical tumor cells form ribbons, tubules or nests, broke the basement membrane of the duct and infiltrate the surrounding tissues or sometimes the tumor cells are arranged in slender linear strands one to two cells across). All the data was entered and analyzed using SPSS-20. Mean and standard deviation for the age and BMI was calculated. Frequencies and percentage were calculated for the categorical variables like age groups, educational level, marital status, residential status, family history and Obesity (Yes/No).

\section{RESULTS;}

Our study comprised of a total of 160 patients meeting inclusion criteria of our study. Of these 160 study cases, $98(61.2 \%)$ were un-married female patients while $62(38.8 \%)$ were married female patients. Mean age of our study cases was $23.23 \pm 3.85$ years (with minimum age of our study cases was 18 years while maximum age was 32 years). Our study results have indicated that majority of our study cases i.e. $123(76.9 \%)$ were aged up to 25 years. Of these 160 study cases, $62(38.8 \%)$ belonged to rural areas and $98(61.2 \%)$ belonged to urban areas while $43(26.9 \%)$ were from poor social background and $117(73.1 \%)$ belonged to middle income families. Family history of breast cancer was positive in $49(30.6 \%)$ of our study cases. Of these 160 study cases, 65 $(40.6 \%)$ were illiterate. Mean body mass index of our study cases was $26.23 \pm 1.92 \mathrm{~kg} / \mathrm{m}^{2}$ and obesity was present in $48(30.0 \%)$ of our study cases. Mean disease duration was $2.98 \pm 2.54$ months and $111(69.4 \%)$ had duration of illness up to 3 months. Breast cancer was noted in $40(25.0 \%)$ of our study cases. 
Table No. 1

\section{Stratification of Breast cancer with regards to family history.}

$$
(\mathrm{n}=160)
$$

\begin{tabular}{|c|c|c|c|}
\hline \multirow[b]{2}{*}{ Family History } & \multicolumn{2}{|c|}{ Breast cancer } & \multirow[b]{2}{*}{$P$ - value } \\
\hline & $\begin{array}{c}\text { Yes } \\
(\mathrm{n}=40)\end{array}$ & $\begin{array}{c}\text { No } \\
(n=120)\end{array}$ & \\
\hline $\begin{array}{c}\text { Yes } \\
(n=49)\end{array}$ & 29 & 20 & \multirow{3}{*}{0.001} \\
\hline $\begin{array}{c}\text { No } \\
(n=111)\end{array}$ & 11 & 100 & \\
\hline Total & \multicolumn{2}{|c|}{160} & \\
\hline
\end{tabular}

\section{DISCUSSION;}

The incidence of breast cancer in Pakistan is highest in Asians after Jews in Israel and 2.5 times higher than that in neighboring countries like Iran and India, accounting for $34.6 \%$ of female cancers. The Pakistani population is deficient in information regarding breast cancer etiology and epidemiology, but efforts done so far had suggested consanguinity as a major risk factor for frequent mutations leading to breast cancer and has also shed light on genetic origins in different ethnic groups within Pakistan ${ }^{9-12}$.

Our study comprised of a total of 160 patients meeting inclusion criteria of our study. Of these 160 study cases, $98(61.2 \%)$ were un-married female patients while $62(38.8 \%)$ were married female patients. A study conducted by Munir et al ${ }^{8}$ has reported similar results. A study conducted by Daudpota et al ${ }^{13}$ has reported $62 \%$ patients with breast lumps were married which is different from our findings.

Mean age of our study cases was $23.23 \pm 3.85$ years (with minimum age of our study cases was 18 years while maximum age was 32 years). Our study results have indicated that majority of our study cases i.e. 123 (76.9\%) were aged up to 25 years. A study conducted by Munir et al ${ }^{8}$ has reported 22.11 years mean age of the patients presenting with breast lumps which is close to our study results. A study conducted by Daudpota et al ${ }^{13}$ has reported similar age groups in compliant to our study results. A study conducted by Niaz et al ${ }^{14}$ has reported 32.96 years mean age which is slightly higher than our study results. The reason for this difference is due to our inclusion criteria; as we only included patients with ages up to 35 years. A study conducted in Lahore by Ali et al ${ }^{15}$ has also reported breast lumps being more common in age groups ranging $20-29$ years which is in compliance with our study results.

Of these 160 study cases, 62 (38.8\%) belonged to rural areas and $98(61.2 \%)$ belonged to urban areas while 43 (26.9\%) were from poor social background and 117 (73.1\%) belonged to middle income families. Family history of breast cancer was positive in $49(30.6 \%)$ of our study cases. Of these 160 study cases, $65(40.6 \%)$ were illiterate. Another study from Karachi ${ }^{16}$ reported $20 \%$ patients of breast cancer had positive family history which is same as that of our study results. de Bruin MA et al ${ }^{17}$ reported as high as $50 \%$ family history of breast cancer in Asian women which is quite higher than that of our study results. Nisar et al ${ }^{18}$ reported $34 \%$ family history was positive in patients with breast cancer which is slightly higher than that of our study results. 
Mean body mass index of our study cases was $26.23 \pm 1.92 \mathrm{~kg} / \mathrm{m}^{2}$ and obesity was present in $48(30.0 \%)$ of our study cases. Mean disease duration was $2.98 \pm 2.54$ months and $111(69.4 \%)$ had duration of illness up to 3 months. de Bruin MA et al ${ }^{17}$ reported similar results. Giasvand et al ${ }^{19}$ reported women with breast cancer had obesity in $39.4 \%$.

Breast cancer was noted in 40 (25.0\%) of our study cases. A study conducted by Daudpota et al ${ }^{13}$ has reported $12 \%$ malignancy which is similar to our results. A study conducted by Niaz et al ${ }^{14}$ has reported $24.2 \%$ breast cancer in patients with breast lumps which is close to our study results. A study conducted in Sudan has reported $34 \%$ breast cancer in patients presenting with breast lumps.

\section{CONCLUSION;}

High frequency of breast cancer was noted in our study among young females presenting with breast lumps. Breast cancer was significantly associated with marital status, increasing age, residential status, socioeconomic status and family history of breast cancer. These findings suggest that females at every age group with breast lumps need specialized care for diagnosis and management.

\section{REFERENCES;}

1. Veisy A, Lotfinejad S, Salehi K, Zhian F. Risk of breast cancer in relation to reproductive factors in North-West of Iran, 2013-2014. Asian Pac J Cancer Prev. 2015;16(2):451-5.

2. Ahmadian M, Samah AA. A model for community participation in breast cancer prevention in Iran. Asian Pac J Cancer Prev. 2012;13(5):2419-23.

3. Iskandarsyah A, de Klerk C, Suardi DR, Sadarjoen SS, Passchier J. Health locus of control in Indonesian women with breast cancer: a comparison with healthy women. Asian Pac J Cancer Prev. 2014;15(21):9191-7.

4. Seth T, Kotwal A, Thakur RK, Ganguly KK. A study on community perceptions of common cancers, determinants of community behaviour and program implementation in New Delhi, India. Asian Pac J Cancer Prev. 2012;13(6):2781-9.

5. Thangjam S, Laishram RS, Debnath K. Breast carcinoma in young females below the age of 40 years: A histopathological perspective. South Asian J Cancer. 2014 Apr;3(2):97-100. doi: 10.4103/2278330X.130441.

6. De Lima Vazquez $\mathrm{F}^{1}$, Silva $\mathrm{TB}^{1}$, Da Costa Vieira $\mathrm{RA}^{2}$, Da Costa $\mathrm{AM}^{1}$, Scapulatempo $\mathrm{C}^{1}$, Fregnani $\mathrm{JH}^{1}$, et al. Retrospective analysis of breast cancer prognosis among young and older women in a Brazilian cohort of 738 patients, 1985-2002. Oncol Lett. 2016 Dec;12(6):4911-24.

7. Ribnikar $\mathrm{D}^{1}$, Ribeiro JM, Pinto D, Sousa B, Pinto AC, Gomes E, et al. Breast cancer under age 40: a different approach. Curr Treat Options Oncol. 2015 Apr;16(4):16. doi: 10.1007/s11864-015-0334-8.

8. Muneer A, Tahir SM, Shaikh GA, Zia A, Shaikh AR, Fatima S. Breast lumps in adolescent and young female: are all benign? J Liaquat Uni Med Health Sci. 2011;10(3):112-6.

9. Butt Z, Haider SF, Arif S, Khan MR, Ashfaq U, Shahbaz U, et al. Breast cancer risk factors: a comparison between pre-menopausal and post-menopausal women. J Pak Med Assoc. 2012;62(2):1204.

10. Kushi LH ${ }^{1}$, Doyle C, McCullough M, Rock CL, Demark-Wahnefried W, Bandera EV, et al. American Cancer Society Guidelines on nutrition and physical activity for cancer prevention: reducing the risk of cancer with healthy food choices and physical activity. Cancer J Clin. 2012;62:30-67.

11. Shaukat $\mathrm{U}^{1}$, Ismail M, Mehmood N. Epidemiology, major risk factors and genetic predisposition for breast cancer in the Pakistani population. Asian Pac J Cancer Prev. 2013;14(10):5625-9.

12. Kamińska $\mathrm{M}^{1}$, Ciszewski $\mathrm{T}^{1}$, Łopacka-Szatan $\mathrm{K}^{1}$, Miotła $\mathrm{P}^{2}$, Starosławska $\mathrm{E}^{1}$. Breast cancer risk factors. Prz Menopauzalny. 2015 Sep;14(3):196-202.

13. Daudpota AQ, Muhammed K, Soomro AH, Rahman H. Young female breast lumps; are all benign? Isra Med J. 2014;6(4):297-300.

14. Niaz MA, Qadri AA, Maqsood M, Ch AK, Niaz M. Malignancy in breast lumps

Professional Med J. 2007;14(2):286-94. 
15. Ali K, Abbas MH, Aslam S, Aslam M, Abid KJ, Khan AZ. Frequency of benign breast diseases in female patients presenting with breast lumps - a study at Sir Ganga Ram Hospital, Lahore. Ann King Edward Med Uni. 2005;11(4):526-8.

16. Memon $\mathrm{ZA}^{1}$, Shaikh AN, Rizwan S, Sardar MB. Reasons for patient's delay in diagnosis of breast carcinoma in Pakistan. Asian Pac J Cancer Prev. 2013;14(12):7409-14.

17. de Bruin MA ${ }^{1}$, Kwong A, Goldstein BA, Lipson JA, Ikeda DM, McPherson L et al. Breast cancer risk factors differ between Asian and white women with BRCA1/2 mutations. Fam Cancer. 2012 Sep;11(3):429-39.

18. Nisar A, Siddiqi MN, Naveed ur Rehman, Raza ur Rehman. Breast cancer; frequency of risk factors. Professional Med J 2014; 21(6):1128-1132

19. Ghiasvand R, Maram ES, Tahmasebi S, Tabatabaee SH. Risk factors for breast cancer among young women in southern Iran. Int J Cancer. 2011 Sep 15;129(6):1443-9. 